\title{
Kurve med skjønnskrift
}

«Efter forslag av avdøde sanitetsgeneral Hans Daae blev der sommeren 1923 paa de fleste eksercerplasser utført en serie av 7 forskjellige idrætsprøver ved rekrutskolens begyndelse,» beretter Schiøtz \& Waaler i Tidsskriftet nr. 16/1927. Resultatene er fremstilt i 11 tabeller. De har beregnet gjennomsnittsverdier og standardavvik og kommer frem til en vakker Gauss-kurve. Det viser seg at for å havne blant de 2,14\% i gruppen «særdeles tilfredsstillende», må man hoppe minst $136 \mathrm{~cm}$, hvilket tilfeldigvis samsvarer nøyaktig med kravet til idrettsmerket. Masseundersøkelser er altså veien å gå for å fastsette slike krav (Tidsskr Nor Lægeforen 1927; 47: 861-8).

\section{Hygiene, social medicin, lageforhold m. v.}

\author{
Norske rekrutters fysiske ydeevne. Idrætsundersøkelser 1923.
}

Av dr. med. Carl Schiøtz og prosektor Georg Waaler.

Vi har først beregnet gjennemsnitsværdierne (det aritmetriske middeltal) for hver enkelt øvelse ved hvert enkelt regiment. Resutaterne sees av tabel 1. Tabel 2 viser variationsforholdene. Variationen omkring gjennemsnitsværdien kan maales ved den saakaldte standardavvikelse, som bestemmes ved hver enkelt ydelses avvikelse fra gjennemsnittet. Dette maal vil nu blandt andet være avhængig av de absolutte størrelser, eksempelvis være større for længdehop (med gjennemsnit $358 \mathrm{~cm}$.) end for høidehop (med gjennemsnit 109). For at kunne sammenligne flere øvelsers variation betragter vi derfor standardavvikelsen i for h o ld til gjennemsnittet (nemlig uttrykt som procent av dette). Dette maal kaldes variationskoefficienten, og det er dette tal, vi har opført i tabel 2. Man ser at der er mindst variation i resultaterne for $60 \mathrm{~m}$. løp, derefter for høidehop, længdehop, kulestøt, kast med fotbal, kast med liten bal og hævning i armene. Bortsett fra kulestøt, som ikke blev prøvet av skoleeleverne, er dette nøiaktig den samme rækkefølge som ved skoleundersøkelserne. Vi har derfor øiensynlig fundet en dypereliggende «lov». Vi kan kanske se det i forbindelse med øvelsernes «naturlighet». Det «naturligste» er løpet, variationerne i præstationeerne blir derfor her mindst, derefter kommer hopøvelserne, saa kastøvelserne og til slut hævning i armene.

Hvis man avsætter standardavvikelsen $(\sigma) 3$ ganger paa hver side av gjennemsnittet, omfatter dette omraade de aller fleste præstationer. Man kan derfor kalde dette for det normale variationsomraade. Dette blir ved standardavvikelsen delt i 6 grupper. Se fig. $\left.{ }^{1}\right)$ Man kunde si, at de to grupper, som ligger nærmest over og under gjennemsnittet, har tilfredsstillende præstationer; betegnet med «meget tilfredsstillende» og «nogenlunde tilfredsstillende». Præstationerne i de to ytterste grupper kunde man betegne med «særdeles tilfredsstillende» og «maatelig». Ved en helt symmetrisk og regelmæssig fordeling vil nu 68,26 pct. (d. e. ca. $2 / 3$ ) av alle ligge i den midterste gruppe, 13,60 pct. i hver av de følgende grupper og 2,14 pct. i de to ytterste grupper. Grændsen for disse grupper er opført i tabel 3. (For hævning i armerne og $60 \mathrm{~m}$. løp, hvor fordelingen er skjæv, er gruppegrænserne beregnet ved hjelp av disse procenttal).

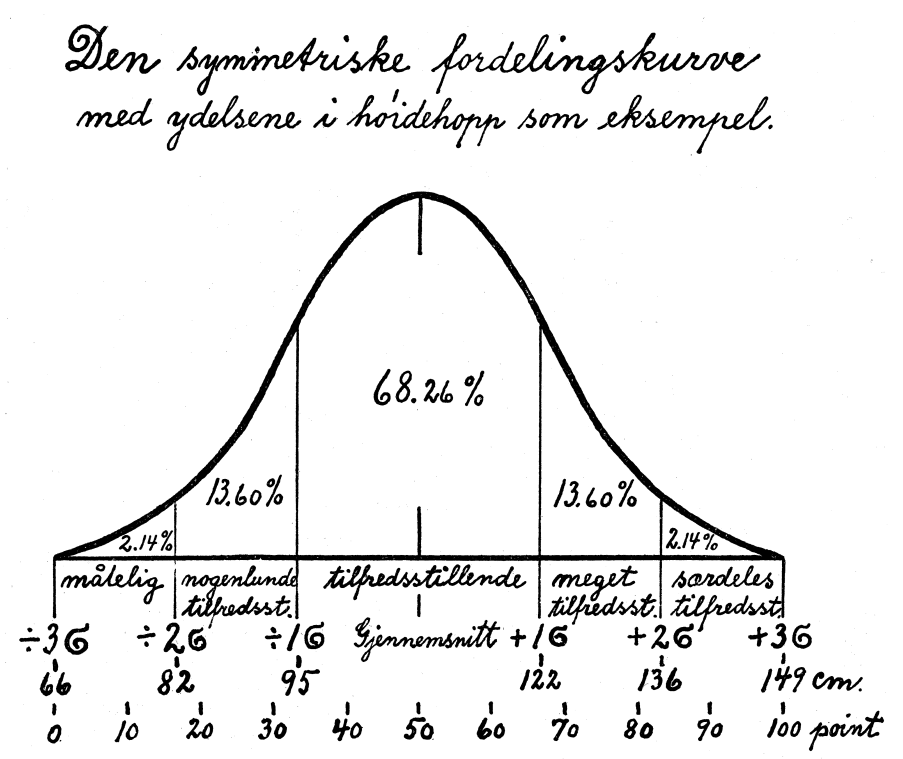

For at komme op i grupperne «særdeles tilfredsstillende» for øvelserne høidehop og længdehop maa man yde henholdsvis mindst 136 $\mathrm{cm}$. og $450 \mathrm{~cm}$. Disse tal kjender vi. De betegner nøiagtig fordringene til idrætsmerket. Den paa det praktiske skjøn byggede, men helt virkaarlige fastsættelse av disse værdier maa derfor ved disse øvelser siges at ha været meget, man kan vel si forbausende heldig. Efter denne samstemmighet mellem den tidligere praksis og vore paa masseundersøkelser byggede resultater kunde vi ønske at fastslaa, at fordringer til idrætsmerket ogsaa for andre øvelser bør bestemmes efter statistiske masseundersøkelser. 